\title{
The children of mama coca: Coca, cocaine and the fate of harm reduction in South America
}

\author{
Francisco I. Bastos ${ }^{\mathrm{a}, *}$, Waleska Caiaffa ${ }^{\mathrm{b}}$, Diana Rossi ${ }^{\mathrm{c}}$, \\ Marcelo Vila ${ }^{\mathrm{c}}$, Monica Malta ${ }^{\mathrm{a}}$ \\ a Oswaldo Cruz Foundation (FIOCRUZ), Rio de Janeiro, Brazil \\ ${ }^{\mathrm{b}}$ Federal University of Minas Gerais (UFMG), Belo Horizonte, Brazil \\ c Intercambios: Asociacion Civil para el Estudio y Atencion de Problemas Relacionados con las Drogas, \\ Buenos Aires, Argentina
}

Received 1 October 2006; accepted 22 November 2006

\begin{abstract}
The paper reviews the main findings from substance misuse research carried out over the last two decades in South America looking at the main initiatives aimed at reducing drug related harm and curbing the spread of HIV/AIDS and other sexually transmitted and blood-borne diseases. The current challenges faced by harm reduction in the region are analysed from the perspective of the history of coca and its different uses in South America. Except in Brazil and Argentina, the implementation of initiatives to reduce drug related harm in South America has been very cautious. The paper aims to link the analysis of harms associated with the use of illicit substances, with the often paradoxically harmful effects of supply-side drug policies in the world's largest coca/cocaine producing area. Despite the undeniable success of many initiatives, the broader context of harm maximization through structural violence and entrenched corruption acts as a major disincentive for the comprehensive adoption of sound public health policies.
\end{abstract}

(C) 2006 Elsevier B.V. All rights reserved.

Keywords: Coca; Cocaine; South America; Drug policy; War on drugs; Harm reduction

When the day is done

And you want to run

Cocaine...

(from the popular song by J.J. Cale)

\section{Introduction}

Before the arrival of the Spanish conquerors, the coca bush was a key crop in the Andes region of South America, a much valued and symbolic commodity (Bastos, 1992). Either chewed or drank as coca infusion or "tea", coca was an important stimulant for the indigenous populations living around the region that nowadays broadly comprises the territories of Peru, Bolivia and Colombia. Spared from the

\footnotetext{
* Corresponding author. Tel.: +55 213865 3231; fax: +55 2122901696 .
}

serious mountain sickness symptoms faced by contemporary tourists by a lifetime of physiological adaptation, indigenous populations have nevertheless been forced to deal with the unpleasant consequences of the very low concentration of oxygen in the Andean heights. Apart from the ruling elites of nobles and priests, the ordinary people living in the Andean region in the 1400s performed strenuous work in the steep areas they used for agriculture and in the mines.

The use of coca was initially a religious sacrament; the plant was viewed as a gift from the gods, to be used under the direct supervision of high priests as well as part of a deity herself, the Queen Mama Coca. With the arrival of the Spanish elite, and a new wave of (Spanish) nobles and (Catholic) priests, coca commenced its journey towards evil and sin, a plant no longer blessed but rather cursed as devilish, powerful and magic. However, as the Spanish conquerors became landowners and traders, the pragmatism of profit pushed theological disputes aside, gradually convincing the Spanish 
rulers to establish a monopoly of coca growing and selling (Bastos, 1992).

Coca chewing and the habit of drinking coca infusion continued throughout the centuries up to modern times, but have been basically restricted to Andean villagers, the descendants of the native Andean populations. On the other hand, cocaine, the main coca derivate (together with associated formulations such as crack cocaine), has found a contemporary consumer market and in turn has become a public health and policy concern.

Initiatives aimed at reducing drug-related harm in South America have been targeting, with some success (as documented below), the harms and risks associated with the use of powder cocaine and, to a lesser extent, the harms associated with the use of crack cocaine. Meanwhile, the production of coca was stripped of its original cultural and social meaning, resurfacing with full vigour in the 1980s, and to be reframed as a war between 'good and evil' as battle was joined enveloping the drug warriors and cartels, criminals and cops, guerillas and corrupt politicians.

Through the prism of protecting and promoting public health, the present paper aims to re-evaluate current policies and initiatives aiming to reduce cocaine-related harm in the broader frame of coca/cocaine production and traffic, and its close links with structural violence, guerilla warfare and violation of human rights in South America.

\section{Harm reduction at the supply-side of the drug war: public health under siege}

The title of this section was borrowed from the title of a paper by Argañarás (1997) on the need to implement initiatives to minimize the untoward effects of supply-side drug policies in Latin America. Ten years after the publication of Arganãras' seminal paper, his proposition remains a challenge and the problems addressed by his analysis have not improved, but as many lay observers and experts have highlighted, actually worsened (Thoumi, 2003; Youngers \& Rosin, 2005).

The challenge to implement rational and democratic alternatives for the cultivation of coca in the Andean countries amidst an ongoing war on drugs, guerilla warfare and structural violence has yet to be answered by local governments or society in general. The very idea of waging a continuous war on drugs constitutes of itself a major challenge for democratically elected governments (Youngers \& Rosin, 2005). One must remember that Latin America has been plagued by harsh dictatorships and short-lived unstable democratic governments. Therefore, any coalition of foreign military advisors and the local army or any attempt (voluntary or involuntary) to blur the limits and specific functions of the military and the police may inadvertently awake the halfdormant ghosts of a recent past of severe violations of human rights, torture and murder. In Colombia, the potential benefits of a full democratic state did not even reach some areas of the country, still under the control of guerillas and paramilitaries (Thoumi, 2003).

It is time now to revisit Argañarás' original ideas from the perspective of the current rising tide of crime, corruption and conflict. Attempts to reduce the supply of coca/cocaine oscillate between efforts to eradicate crops on the one hand, and crop substitution on the other, with main staples such as corn or beans. Experts have been unanimous in their condemnation of crop eradication as a viable strategy in isolation for the simple fact that the aggregated coca acreage has not been decreasing because crops have been displaced rather than eradicated. And not only have such policies failed, but they have been accompanied by substantial ecological damage; virgin areas have been deforested and the environment has been polluted with long-lasting herbicides. But, above all, attempts at eradication have deprived poor peasants and their families of their main source of income. So if any valid attempt is to be made to minimize (rather than aggravate) harms associated with coca/cocaine supply, this must focus on crop substitution. So what are the challenges ahead for crop substitution initiatives?

Crop substitution does not take place in a vacuum; it can only become a viable and acceptable alternative in the context of comprehensive action toward sustainable development. "Sustainable" here means, first of all, ecologically sound and culturally appropriate, i.e. initiatives which spare (and ideally protect and even reconstitute) the local ecology, degraded by the combined effect of deforestation, bad agricultural management (commonplace in the agricultural practices of impoverished peasants, especially those permanently trying to evade detection) and a herbicide-laden environment. Since there is no longer something we can consider pristine ecosystems, "ecology" and "sustainable" here means to make environment management compatible with the human uses of environment (Diamond, 2005). In this sense, any ecologically sound proposal must be culturally sensitive and tailored to the needs and habits of local people.

However, any well-intentioned proposition would be meaningless if economically impractical and not sustainable from the perspective of both the local and national economies. This is a crucial because of the huge sums of money circulating in the commercial network anchored in (but not restricted to) the coca bush fields - the ultimate source of cocaine as a commodity, but the weakest link of its long commercial chain.

Peasants never get the lion-share of the coca/cocaine market, except those peasants who became illicit "agrobusinessmen" themselves, i.e. those engaged not only in coca cultivation, but also in coca/cocaine refining, selling and distribution. Even so, the illicit market spends part of its vast profits on infrastructure, such as better roads to transport goods and the working force or cash to finance new crops or to compensate for natural disasters and other unfortunate events. In this sense, the influence of the illicit networks extends much beyond the purchase of coca leaves from individual peasants and their families. 
Taking these considerations into account, supply-side harm reduction means, first of all, integrated efforts toward comprehensive national and local development. A continuous dialogue with the civil society and authorities at different levels constitutes a precondition of such initiatives, and, of course, such dialogue is seriously jeopardized if not silenced by the drums of war.

\section{Coca/cocaine trafficking as a key element of guerrilla warfare, structural violence and corruption}

The massive profits associated with the coca/cocaine illicit market along the production-distribution continuum and the oligopolistic features of many of its key steps - including the establishment of local production/distribution cartels and the networks of big retailers operating in the major metropolitan areas, worldwide - make cocaine a very attractive commodity for individuals and groups seeking high and quick profits.

In the context of political instability, conflict and dire poverty, violence - an essential component of illegal markets establishment and maintenance - is easily woven into the fabric of criminal networks involved not only with drug dealing, but also robbery, kidnappings, extortions and murders. Moreover, violence is not simply contained within the world of organized crime and gangsterism (turf wars, settlement for bad debts, etc.) but has leaked into mainstream society, gaining a momentum on its own and creating a vicious circle of murders and paybacks.

At different times in 2006, Latin America's second largest city, São Paulo, inhabited by more than 12 million people, almost ground to a halt following orchestrated attacks against police stations, commercial facilities, public transport, etc. At its peak, successive attacks killed more than 300 people in a couple days (Anon., 2006), a casualty rate on a par with Iraq, a country fighting explicit insurgence.

Violence has been endemic in most parts of Colombia (Thoumi, 2003) and, as in major Brazilian metropolitan areas like Sao Paulo, it has been increasingly perpetrated by organized criminal factions. In present day Brazil, such factions operating under evocative names like the "Primeiro Comando da Capital" (the "First Commando of the Capital", aka PCC) are not tinted by the colours of left or right-wing politics, such as in Colombia (however messy and self-contradictory such political affiliations have been there; Thoumi, 2003). But the overarching idea of controlling a "territory", whether territory means a strip of land in the countryside or the hypothetical control over the largest city of Brazil, prevails in both countries. Citizens have been deprived of their basic rights, such as their right to live in certain areas, to move around at certain times or in certain places and to pursue their day to day occupations (waves of violence in Brazil have been always preceded by informal fast-spreading warnings to "close the shops immediately or to be vandalized") (Anon., 2006).

Such scary scenarios, unfortunately present in much of modern-day Latin America, have stimulated the political hawks and warmongers, both domestically and overseas, to simply increase the dose of the same medicine, reasoning that current dilemmas are not the consequences of mistaken drug policies, but rather the result of an insufficient dose of an already biter pill.

Policies aimed at curbing the harms caused by cocaine consumption and those aimed at restricting supply are often in conflict. But despite the repeated admonitions of many observers (e.g. Youngers \& Rosin, 2005) that any hope of reconciling these differences and moving forward must incorporate the preservation of democracy and the protection of human rights in its very core (and not as an afterthought), momentum has been moving in the opposite direction. Current policies are fostering an ascending spiral of violence and sheer disrespect for the most fundamental and valued human rights.

Any genuine attempt to reverse the current trends towards harm maximization in Latin America means a fundamental redefinition of domestic drug policies and joint initiatives of national governments and foreign countries. Although the steps toward such profound reform extend well beyond the scope of the current text, we will mention here a couple recent albeit cautious initiatives in this direction.

Although modest vis-à-vis its original propositions, recent drug law reform in Brazil (August 2006) can be viewed as an achievement. After years under revision in the Congress, the new drug law establishes a clear distinction between the personal possession and use of small amounts of illicit drugs from trafficking, proposing the use of fines and/or "service to be delivered the community" instead of imprisonment for drug users (Agência Brasil/Radiobrás, 2006). Whether such reform will minimize current unacceptable levels of corruption in the judiciary and the police is yet to be verified. Anyway, it seems to reform oriented Brazilians to be a useful step toward emptying overcrowded and filthy prisons, the cradle where factions such as PCC thrive. Prisons have been the key places where city-wide waves of destruction and generalized violence originate, through coordinated rebellions within the walls of different prisons after orders spread from cell phones used inside the prisons to vandalize and kill people living outside the prison walls.

Attempts have also been made by different Latin American countries to position national sovereignty as an indisputable cornerstone of any proposed cooperation with foreign countries and organizations. Such attempts are not without risk due to the flagrant inbalance of power and resources any Latin American country compared to the political and military power mobilized by rich countries, especially the USA. Another risk, from what could be called the "left" (or at least something viewed as such by their own proponents), is to bypass once again the pillars of democracy and respect for the humans rights in favour of a mix of anti-imperialistic rhetoric and compromises with guerillas and criminal factions.

There are no magical solutions to bringing about genuine harm minimization policies. The only hope from our point of view, is a continuous debate involving all constituents 
of national societies and their international counterparts. It might appear that the process is slow and ineffective, but to quote the popular adage — ageing is a painful process but the alternative is even worse.

\section{Structural violence and poverty as a deterrent of public health initiatives}

In a recently published paper, Rhodes et al. (2006) propose a debate on the pivotal role of the environment in the minimization/maximization of the risks and harms linked to injection of illicit drugs and the spread of blood-borne infections. The main point raised by Rhodes et al. is the need to move beyond the individual dimension of risks and the measures to avert or minimize them, to consider a wider environmental context.

Risky and threatening environments not only jeopardize the attempts of individuals and their social networks to adopt safer behaviours, but in areas where violence escalates to the point of becoming structural (i.e. endemic and entrenched in the daily habits and attitudes), may function as a key deterrent to the implementation of any effective public policy.

Nowadays, favelas (slums) in Rio de Janeiro and other deprived communities in Brazil face the challenge posed by structural violence, mistrust and lack of social cohesion and mutual cooperation. Even researchers with close and longterm contact with local communities, such as the researchers from the Oswaldo Cruz Foundation (FIOCRUZ) - the largest biomedical institution in Latin America - have seen their attempts to carry out public health projects frustrated. Most of those projects are vital for these communities, such as the improvement of basic sanitation through the use of simple and cheap alternatives developed at FIOCRUZ and already successfully piloted in the same favelas. Visitors touring FIOCRUZ are often shocked to see the sheer contrast between the state-of-the-art factories (including the largest industrial plant for yellow fever vaccine, worldwide) and dire poverty, just separated by a dirty rivulet. The inhabitants of the surrounding favelas themselves coined the term "Gaza strip" for the worst parts of their community, where a dozen people are murdered every day. Many attempts have been made to improve such conditions, like giving priority to local community members as students at FIOCRUZ vocational school (recently ranked as the best public high-school, in Brazil) and to selectively hire members of local communities as workers at FIOCRUZ factories and other facilities that currently employ more than 7000 people.

But the situation seems to be deteriorating despite such laudable initiatives and is even worse in other favelas where partnerships with any level of government is virtually nonexistent. Visitors are always viewed as informants, and police conduct regular raids not in regular patrol cars and using traditional weaponry, but in small tanks, suggestively called "caveirão" (the "big skull"). It is difficult to conceive where such escalation of violence will lead, but one may specu- late that decades of mutual mistrust between communities and administrators, police corruption and progressive demoralization of native leaderships (progressively replaced by criminals from different factions) will hamper any serious attempt to carry out initiatives to improve community life including public health.

In sum, current challenges faced by individuals and groups trying to foster initiatives to reduce drug-related harms, are deeply entangled with the very drug policies that, in theory should ameliorate the problems they are in fact aggravating.

\section{Drug consumption and the spread of HIV/AIDS and other infections in South America}

Despite its shared heritage, South America encompasses great diversity. The region is home to weak economies, such as Bolivia, while others like Brazil and Argentina, boast strong institutions, civil society groups, academic centres of excellence and reasonable health infrastructure. Yet even within these large, more developed countries, deep social and regional inequalities are especially marked (Hacker, Malta, Enriquez, \& Bastos, 2005) and have uniquely influenced local and national responses to the HIV/AIDS epidemic and local drug policies, resulting in examples of both astonishing success and disappointingly slow progress.

Until now, most South American countries have based their drug policies on a low tolerance and a "drug free" oriented approach (Rodríguez, Marques, \& Touzé, 2002). Authorities use legal sanctions to deal with the problem, employing tactics of repression and obligatory abstinencebased treatment. Until the mid-1990s, strategies aiming to reduce drug-related harm, such as syringe exchange programs (SEPs), were usually unsystematic, narrowly focused, and did not scale up (Rodríguez et al., 2002). Since the late 1990s, however, successful prevention efforts targeting injecting and non-injecting drug users have been developed in the region. SEPs, as well as other outreach initiatives implemented by governments, non-governmental organizations (NGOs) and community based organizations (CBOs) have been targeting injecting drug users (IDUs) with Brazil and Argentina taking the lead in the region (Hacker et al., 2005; Rossi, Goltzman, Cymerman, Touze, \& Weissenbacher, 2003).

Multi-sectoral responses are essential to overcoming the synergy between HIV/AIDS epidemic and drug use. South America has a diversity of political, social and other civil society organizations. Over the years, the number of nongovernmental organizations contributing to the response has steadily increased, and many, though not all, countries have actively supported them in this role. However, a wide gap remains between community needs and the capacity of such organizations to meet them (Paiva, Ayres, Buchalla, \& Hearst, 2002).

Networking is a key instrument for harm reduction development and drug policy reform in Latin America. The Latin American Harm Reduction Network (RELARD) founded in 
1998 disseminates research findings, literature and best practices. Its activities seek to consolidate regional cooperation to increase the local capacity to scale up harm reduction strategies in the region. RELARD cooperation with national and international organizations assists the organization of training, fundraising, information circulation, human rights activism and the mobilization of harm reduction efforts (RELARD, 2006; Rodríguez et al., 2002).

Despite the successful of many initiatives, the harmful use of illicit drugs, especially cocaine, has been on the rise in different parts of South America, and has been associated with the spread of HIV/AIDS and other sexually transmitted and blood-borne infections. The situation is of special concern in southern Brazil (Pechansky et al., 2006) and the Southern Cone (i.e. Argentina and Uruguay) (Vignoles et al., 2006).

While injecting drug is a well known major risk factor for hepatitis $\mathrm{C}(\mathrm{HCV})$ and $\mathrm{HIV}$ infections, non-injecting drug use (e.g. inhaled or smoked cocaine) has been described as a risk factor for both infections, with consistent findings of higher prevalence of HIV and HCV infection among non-injecting cocaine users than in the general population (Caiaffa et al., 2006; Howe et al., 2005). The harms and risks associated with non-injecting drug use have been seldom targeted by integrated harm reduction initiatives in South America.

\section{Chile}

During almost 20 years of dictatorship, led by Augusto Pinochet (1973-1990), the regime prioritized economic development to the detriment of public health which received little attention. Until the 1990s the country did not have any health or mental health policy targeting the drug using population, and the only initiatives were targeted at the control of the drug traffic and the detention of drug users (Ortiz Rebolledo \& Costa, 2005).

Chile is an important trans-shipment country for cocaine destined for Europe, and according to recent reports domestic cocaine consumption is rising (Inter-American Drug Abuse Control Commission, 2006). But even with a rising illicit drug problem, until recently the country had not provided sterile equipment to IDUs nor implemented any harm reduction projects (Rodríguez et al., 2002).

\section{Colombia}

Colombia is the world's leading coca cultivator and largest producer of coca derivatives; supplying most of the US market and the great majority of cocaine to other international drug markets (Thoumi, 2003).

An intervention coordinated by Ross (2002) using rapid assessment methods was conducted in the country's capital Bogotá. The study and concurrent intervention explored patterns of drug use and risky behaviours related to overdose, crime, violence, sexually transmitted infections (STIs) and HIV/AIDS among drug users who frequent a downtown area of Bogota called "Calle 19" (19th Street). The study con- ducted interviews with several drug users and dealers, and implemented health promotion activities and harm reduction strategies. According to study participants, the violence related to drug dealing and to police harassment is perceived as more dangerous than the sexual and health risks of taking drugs. Lack of health insurance limited participants access to both health care and to drug dependence treatment. The project identified and worked closely with some peer leaders, who conducted peer-education activities and engaged at-risk individuals in treatment and care. The partnership between study staff and community leaders contributed to creating better bridges between at-risk individuals and health interventions, thus contributing to a reduction in HIV/AIDS risk behaviours (Ross, 2002).

A recent report by Stimson et al. (2006) evaluated the impact of the World Health Organization's rapid assessment and response method in several settings, including in Bogota. According to the study, Colombia does not have government programs aimed at preventing health problems in drug using and specifically drug injecting populations. The authors identified three main gaps in the available interventions targeting drug using population in Colombia: (1) need to develop policies and actions to prevent transition to IDU and address the risks involved in IDU; (2) need to develop educational and preventive strategies addressing specific problems and gaps in information levels and risk perceptions of drug users; (3) need to develop programs and actions to reduce the adverse health consequences of drug use.

\section{Uruguay}

In Uruguay, around $80 \%$ of drug treatment centres are private and strictly oriented toward abstinence (Osimani, 2003). According to a study conducted in 2001 by the NGO Instituto de Investigación y Desarrollo Social (IDES), 11\% of those institutions mentioned that people living with HIV/AIDS who were drug dependents were not admitted to their treatment programs (Osimani, 2003).

During 2000, UNAIDS and UNDCP developed a project in Argentina, Chile, Paraguay and Uruguay to foster a broader response to HIV/AIDS and drug use in the Southern Cone countries. The project funded a series of activities in the fields of prevention and care for drug users and vulnerable populations; awareness creation for the general public as well as for specific groups; research in the four countries under a common approach developed jointly with governmental institutions, NGOs, UNAIDS and UNDCP (Riley, 2003).

In 2001, IDES organized an intervention program targeting the injecting and non-injecting drug users and their sexual partners who frequented a high-risk neighbourhood. The intervention provided training, information materials and condoms, but did not provide injection paraphernalia, since there is no legal support for such an activity in Uruguay. To the best of our knowledge, until now, Uruguay does not provide sterile syringes and needles to IDUs, regardless of the grow- 
ing IDU population accessed by researches and interventions targeting general drug using population.

\section{Paraguay}

Until recently Paraguay did not provide sterile materials to IDUs, neither had any harm reduction project, although small projects were already accessing several IDUs. Since 2004, the Ypejhú Municipality, Canindeyu, has given important backing to harm reduction interventions, promoting the handing out of free syringes. A recent Decree from this Municipality calls for: "[the] distribution of disposable syringes in exchange for used syringes". This initiative represents an attempt to launch harm reduction in the municipality, but it is still tentative and restricted to a small area (Intercambios, 2006).

\section{Argentina}

According to data from Argentina's Ministry of Health, the shared use of injection paraphernalia has been the main transmission route of HIV/AIDS in Argentina until recently, and corresponds to approximately one-third of the accumulated 30,498 AIDS cases (up to 2005). Currently, the most frequent transmission route is unprotected sex among heterosexuals (Argentina Ministry of Health and Environment, 2006).

The implementation of harm reduction polices in Argentina has been erratic, combining major achievements with setbacks (Hacker et al., 2005; Inchaurraga, 2003). Although facing an HIV/AIDS epidemic among IDUs, Argentina still lacks large-scale harm reduction programs at national and state (provincial) levels (Inchaurraga, 2003; Rossi et al., 2003).

As in Brazil, cocaine is the most frequent injected substance in Argentina while heroin injection has been negligible (Hacker et al., 2005; Sosa-Estani, Rossi, \& Weissenbacher, 2003). Sero-prevalence studies carried out in the 1980s/1990s pointed to disquieting levels of needle-sharing and HIV infection rates (ranging from 27 to $80 \%$ ), depending on the specific sub-population and region under analysis (Sosa-Estani et al., 2003).

The prevailing drug policy in Argentina is still based on strict abstinence, and starting in the mid-1970s, there have been harsh punishments for drug possession. Following a pattern seen in several Latin American countries, the Argentinean military dictatorship during the 1970s/1980s highly influenced interventions and policies related to the re-education and rehabilitation of drug users. Psychiatric hospitals and prisons have been responsible for drug dependence treatment (Hacker et al., 2005).

Since the mid-1980s, non-governmental rehabilitation centres have piloted alternative treatment approaches, mainly following Therapeutic Community models. Also, during the mid-1980s, penal punishments for drug possession were reviewed. If those caught in possession demonstrated that drugs were only intended for personal use, they might be required to complete compulsory treatment without incarceration (Siri \& Inchaurraga, 2000). Nevertheless, most of the drug-related criminal convictions in Argentina are still related to possession of small amounts of illicit drugs for personal use (Inchaurraga, 2003).

Until recently the majority of harm reduction initiatives have been implemented in the two largest cities in Argentina, Rosario and Buenos Aires (Siri \& Inchaurraga, 2000), where the distribution of sterile injection equipment began in 1999 (Inchaurraga, 2003).

In recent years, with the central role of international cooperation agencies, such as UNAIDS, and benefiting from the South-South cooperation with other Latin American countries, Argentina's drug policy became more dynamic and open to reform. NGOs' central role has been recognized by the government and the international agencies, and has been key in the effort to reach hard-to-reach populations, such as IDUs, and to increase the effectiveness of interventions implemented in the country. A good example of such activities, carried out by the NGO Intercambios, from Buenos Aires, comprise several rapid assessment and response studies. Intercambios organizes training in the field of harm reduction, coordinates pharmacy-based SEPs, and provides a broad range of community interventions, including educational materials (Intercambios, 2006).

\section{Brazil}

Due to its important socioeconomic role in South America and the scope of its HIV/AIDS epidemic, the reformulation of Brazilian HIV/AIDS prevention and drug policies has had a significant impact upon activities in most countries of South America.

The first attempt to implement harm reduction strategies in Brazil occurred in the city of Santos in 1989. However, during that era, the Attorney General from São Paulo filed civil and criminal actions against the program organizers and the city government of Santos. Needle exchange initiatives were interpreted as a means to "stimulate the consumption of drugs". The first SEP in South America was implemented in Salvador, Bahia, in 1994, 5 years after that first abortive attempt (Fonseca, Ribeiro, Bertoni, \& Bastos, 2006).

The drug scene in Brazil is experiencing substantial changes, but the current drug of choice among the Brazilian IDUs population is still cocaine (Cintra, Caiaffa, \& Mingoti, 2006) with recent increases in the use of both cocaine powder and crack alongside newer synthetic drugs (Almeida \& Silva, 2005) and the further spread of more traditional forms of drug use such as solvent sniffing (Thiesen \& Barros, 2004).

The HIV/AIDS epidemic has been especially dynamic in Brazil. After a period of continuous spread of HIV among the so-called "general population" (although with a clear bias toward the dispossessed) since the mid-1990s, the epidemic is currently following a pattern we can tentatively call "partial (re)concentration". Some particularly vulnera- 
ble populations, far from the mainstream social groups who possess greater capacity for mobilization and advocacy, have been especially affected. The spread of HIV/AIDS to these more vulnerable groups such as men who have sex with other men (MSM)-IDUs, women-IDUs and IDUs living in dire poverty are relatively invisible to lay opinion, the media and many policymakers, but they will be especially disadvantaged because of social inequality, gender inequality and homophobia (Cardoso, Caiaffa, \& Mingoti, 2006; Cintra et al., 2006; Ferreira, Caiaffa, Bastos, \& Mingoti, 2006).

Preliminary compilations of available information indicate that more than one hundred SEPs currently operate within Brazil in different regions, states and municipalities. These programs are being implemented by universities, governmental institutions, such as health secretaries and NGOs (Fonseca et al., 2006). No other South American country has officially endorsed SEPs, other than those implemented in Argentina.

Despite funding restrictions and lack of managerial expertise of most SEPs, support for harm reduction initiatives is growing in Brazil. Advocacy activities and lobbying have helped to pass several state laws permitting the implementation of SEPs and similar activities.

Regional and national networks have been established, functioning as forums for ideas and practical experiences with respect to SEPs and other harm reduction initiatives. In Brazil, there are two national harm reduction associations - the Brazilian Harm Reduction Association (ABORDA) and the Brazilian Harm Reduction Network (REDUC) and several local networks. Support from international agencies such as UNAIDS and the World Bank has been necessary to both introduce and sustain SEPs in Brazil. The task in the future will be to expand these programs and to integrate an evaluation framework (Fonseca et al., 2006).

A recent evaluation of Brazilian SEPs operation was conducted in 2004/2005. The study reported that the 45 Brazilian SEPs evaluated usually face coverage and monitoring difficulties and struggle to find and maintains trained personnel, as the majority of Brazilian NEPs personnel work on a part-time basis. In order to improve harm reduction initiatives in Brazil, the authors highlight the need to develop local and regional databanks, conduct regular monitoring and evaluation studies and develop incentives/sanctions to foster accountability of initiatives (Fonseca et al., 2006).

\section{Final remarks}

The challenges raised by drug use in South America have spawned proposals ranging from simply cracking down on drug users to the concerted use of a plurality of actions aimed at minimizing demand for illicit drugs and reducing the harms resulting from such consumption, focusing on education and public health.

Brazil and, more recently, Argentina have offered the world, and especially the other developing countries, invalu- able lessons on how to combine public policies with respect for the autonomy of social movements. Despite the deep economic and social crisis faced by Argentina in the late 1990s, the main prevention projects were slowed down, but not discontinued. Both countries have subsequently introduced policies guaranteeing universal access to antiretroviral medicines, including access for a sizeable number of drug users (Aceijas et al., 2006). Universal access has been proposed but implemented with some difficulties in other South American countries. Initiatives aiming to reduce drug related harm have been relatively cautious in the other South American countries, with some successful, but still limited initiatives, in countries such as Uruguay and Colombia.

The best practices in South America in the field of drug use and HIV/AIDS prevention and management, such as in some localities from Brazil and Argentina, comprise a broad range of HIV prevention programs ranging from HIV testing and counselling, education, behavioural and network interventions, drug use treatment, needle exchange and expanded syringe access, as well as interventions aiming to reduce transition to injection and other harmful practices.

In common with drug users across the world, those in South America, face several clinical conditions in addition to HIV/AIDS, including other blood-borne/sexually transmitted infections (Caiaffa et al., 2006; Vignoles et al., 2006; Zocratto et al., 2006), mental illness (Razzouk, Bordin, \& Jorge, 2000), as well as family and social problems and high levels of social stress including social isolation and poverty. In the main urban areas of South America, violence and the constant violation of basic human rights have been unacceptably high and brutal with frequent mass murders and torture.

In the near future it will be increasingly difficult, if not impossible, to ameliorate the living conditions of people who use illicit drugs and/or live with different clinical conditions, such as HIV/AIDS and hepatitis C, without reversing current unacceptable levels of structural violence and disrespect for human dignity which prevail across South America. The best efforts of community leaders, NGOs and wellintentioned public health officials have been thwarted by the sheer violation of human rights and intimidation of community members, activists and health professionals by gangs, corrupt policemen and paramilitaries.

In our opinion, sound public health policies must be necessarily complemented by a fundamental reform of drug policies and the implementation of broad public policies aiming to ameliorate the untoward consequences of dire poverty, discrimination and criminalization.

\section{References}

Aceijas, C., Oppenheimer, E., Stimson, G. V., Ashcroft, R. E., Matic, S., \& Hickman, M. (2006). Antiretroviral treatment for injecting drug users in developing and transitional countries 1 year before the end of the "treating 3 million by 2005 . Making it happen. The WHO strategy" ("3 by 5"). Addiction, 101(9), 1246-1253. 
Agência Brasil/Radiobrás. (2006). Lula sanciona nova lei sobre drogas. Available at: http://www.agenciabrasil.gov.br/noticias/2006/ 08/23/materia.2006-08-23.0476323709/view. Accessed on October 1, 2006.

Almeida, S., \& Silva, M. (2005). Characteristics of ecstasy users in Sao Paulo, Brazil. Subst. Use Misuse, 40(3), 395-404.

Anon. (2006). Series of reports on the violence in São Paulo (Brazil's Congress Extraordinary Hearings). Available at: http://noticias.terra. com.br/brasil/guerraurbana/interna/0,OI1135699-EI7061,00.html. Accessed on October 1, 2006.

Argañarás, F. G. (1997). Harm reduction at the supply side of the drug war: The case of Bolivia. In P. G. Erickson, D. M. Riley, Y. W. Cheung, \& P. A. O'Hare (Eds.), Harm reduction: A new direction for drug policies and programs. Toronto/Buffalo/London: University of Toronto Press.

Argentina Ministry of Health and Environment, National AIDS Program. (2006). Boletín sobre VIH/SIDA en la Argentina, No. 24, September 2005. Available at: http://www.msal.gov.ar/htm/site/sida/site/pdf/. Accessed on October 1, 2006.

Bastos, F. I. (1992). Cocaína: Uma carreira na história. In O. D. Gonçalves \& F. I. Bastos (Eds.), Cocaine: A historical perspective. Só Socialmente .... Rio de Janeiro: Relume-Dumará.

Caiaffa, W. T., Osimani, M. L., Marinez, L. P., Radulich, G., Latorre, L., Muzzion, E., et al. (2006). HIV and hepatitis $\mathrm{C}$ virus among self declared non-injecting cocaine users (NICUs) in two countries in South America. In XVI international AIDS conference, Vol. 1 (CD-ROM) (p. 0401).

Cardoso, M. N., et al. (2006). AIDS incidence and mortality in injecting drug users: The AjUDE-Brasil II project. Cad Saúde Pública, 22(4), 827838.

Cintra, A. M., et al. (2006). Characteristics of male and female injecting drug users of the AjUDE-Brasil II project. Cad Saúde Pública, 22(4), 791-802.

Diamond, J. (2005). Collapse. How societies choose to fail or survive. London: Penguin Books.

Ferreira, A. D., et al. (2006). Profile of male Brazilian injecting drug users who have sex with men. Cad Saúde Pública, 22(4), 849-860.

Fonseca, E. M., Ribeiro, J. M., Bertoni, N., \& Bastos, F. I. (2006). Syringe exchange programs in Brazil: Preliminary assessment of 45 programs. Cad Saúde Pública, 22(4), 761-770.

Hacker, M. A., Malta, M., Enriquez, M., \& Bastos, F. I. (2005). Human immunodeficiency virus, AIDS, and drug consumption in South America and the Caribbean: Epidemiological evidence and initiatives to curb the epidemic. Rev. Panam. Salud Publica, 18(4-5), 303-313.

Howe, C. J., Fuller, C. M., Ompad, D. C., Galea, S., Klobin, B., Thomas, D., et al. (2005). Association of sex, hygiene and drug sharing with hepatitis $\mathrm{C}$ virus infection among non-injecting drug users in New York City. Drug Alcohol Depend., 79(3), 389-395.

Inchaurraga, S. (2003). Drug use, harm reduction, and health policies in Argentina: Obstacles and new perspectives. Clin. Infect. Dis., 37(Suppl. 5), S366-S371.

Inter-American Drug Abuse Control Commission (CICA/OAS). (2006). Available at: http://www.cicad.oas.org/en/default.asp. Accessed on October 1, 2006.

Intercambios. (2006). Available at: http://www.intercambios.org.ar. Accessed on October 1, 2006.

Ortiz Rebolledo, N., \& Costa, M. C. (2005). Meanings and contradictions of the drugs phenomenon: Legal and illegal drugs in Chile. Rev. Lat. Am. Enfermagem, 13, 903-911 [Special issue]
Osimani, M. L. (2003). The challenge of implementation of preventive programs in a developing country: Experiences, situations, and perspectives in Uruguay. Clin. Infect. Dis., 37(Suppl. 5), S422-S426.

Paiva, V., Ayres, J. R., Buchalla, C. M., \& Hearst, N. (2002). Building partnerships to respond to HIV/AIDS: Non-governmental organizations and universities. AIDS, 16(Suppl. 3), S76-S82.

Pechansky, F., Woody, G., Inciardi, J., Surratt, H., Kessler, F., Von Diemen, L., et al. (2006). HIV seroprevalence among drug users: An analysis of selected variables based on 10 years of data collection in Porto Alegre, Brazil. Drug Alcohol Depend., 82(Suppl. 1), S109-S113.

Razzouk, D., Bordin, I. A., \& Jorge, M. R. (2000). Comorbidity and global functioning (DSM-III-R Axis V) in a Brazilian sample of cocaine users. Subst. Use Misuse, 35(9), 1307-1315.

RELARD. (2006). Available from http://www.relard.net/. Accessed on October 1, 2006.

Rhodes, T., Kimber, J., Small, W., Fitzgerald, J., Kerr, T., Hickman, M., et al. (2006). Public injecting and the need for 'safer environment interventions' in the reduction of drug-related harm. Addiction, 101(10), $1384-1393$.

Riley, D. (2003). An overview of harm reduction programs and policies around the world: Rationale, key features and examples of best practices. In Paper presented at the second international policy dialogue on HIV/AIDS

Rodríguez, C. M., Marques, L. F., \& Touzé, G. (2002). HIV and injection drug use in Latin America. AIDS, 16(Suppl. 3), S34-S41.

Ross, T. (2002). Using and dealing on Calle 19: A high risk street community in central Bogotá. Int. J. Drug Policy, 13, 45-56.

Rossi, D., Goltzman, P., Cymerman, P., Touze, G., \& Weissenbacher, M. (2003). Human immunodeficiency virus/acquired immunodeficiency syndrome prevention in injection drug users and their partners and children: Lessons learned in Latin America-the Argentinean case. Clin. Infect. Dis., 37(Suppl. 5), S362-S365.

Siri, P., \& Inchaurraga, S. (2000). 'First steps': Using rapid assessment and response methods to develop research, intervention and advocacy capacity for addressing drug use in Rosario City, Argentina. Int. J. Drug Policy, 11(1-2), 125-132.

Sosa-Estani, S., Rossi, D., \& Weissenbacher, M. (2003). Epidemiology of HIV/AIDS in injecting drug users in Argentina: High seroprevalence of HIV infection. Clin. Infect. Dis., 37(Suppl. 5), 338-342.

Stimson, G. V., Fitch, C., Des Jarlais, D., Poznyak, V., Perlis, T., Oppenheimer, E., et al. (2006). Rapid assessment and response studies of injection drug use: Knowledge gain, capacity building, and intervention development in a multisite study. Am. J. Public Health, 96(2), 288-295.

Thiesen, F., \& Barros, H. (2004). Measuring inhalant abuse among homeless youth in southern Brazil. J. Psychoactive Drugs, 36(2), 201-205.

Thoumi, F. E. (2003). Illegal drugs, economy and society in the Andes. Washington/Baltimore/London: Woodrow Wilson Center Press/The Johns Hopkins University Press.

Vignoles, M., Avila, M. M., Osimani, M. L., de Los Angeles Pando, M., Rossi, D., Sheppard, H., et al. (2006). HIV seroincidence estimates among at-risk populations in Buenos Aires and Montevideo: Use of the serologic testing algorithm for recent HIV seroconversion. J. Acquir. Immune Defic. Syndr., 42(4), 494-500.

Youngers, C. A., \& Rosin, E. (Eds.). (2005). Drugs and democracy in Latin America. Boulder/London: Lynne Rienner Publisher.

Zocratto, K. B. F., et al. (2006). HCV and HIV infection and co-infection: Injecting drug use and sexual behavior, AjUDE-Brasil I project. Cad Saúde Pública, 22(4), 839-848. 